\title{
Growing maize silage in dairy effluent paddocks for two consecutive seasons - effect on crop yield and soil nitrogen
}

\author{
P. JOHNSTONE ${ }^{1}$, M. PARKER ${ }^{2}$, G. KAUFLER ${ }^{3}$, N. ARNOLD ${ }^{1}$, \\ A. PEARSON ${ }^{2}$, D. MATHERS ${ }^{2}$ and D WALLACE ${ }^{1}$ \\ ${ }^{1}$ The New Zealand Institute for Plant \& Food Research Limited, Private Bag 1401, Havelock North \\ ${ }^{2}$ Foundation for Arable Research, PO Box 80, Lincoln \\ ${ }^{3}$ Environment Waikato, PO Box 4010, Hamilton \\ Paul.Johnstone@plantandfood.co.nz
}

\begin{abstract}
Nutrient loading can be high in dairy-farm soils that are regularly irrigated with shed effluent, especially when the area treated is small or the farming system has intensified. Negative effects on animal health and the environment can occur as a consequence. In 2007, a 3 year project commenced to explore opportunities to mitigate these impacts through the strategic use of maize. Nine on-farm trials have shown that nitrogen (N) fertiliser is not necessary to maximise maize silage yield for first year crops planted in nutrient-rich, effluent treated soils. An additional two trials indicated that this $\mathrm{N}$ reserve can also meet all or most of the crop $\mathrm{N}$ demand in second year crops. This approach allowed fertiliser costs to be eliminated or minimised. It also reduced residual soil mineral $\mathrm{N}$ levels at harvest. Further work is required to give farmers certainty as to when extra fertiliser is required, particularly in the second year.
\end{abstract}

Keywords: nitrogen, shed effluent, Zea mays

\section{Introduction}

Managing nutrients on intensive dairy farms is a challenge for the dairy industry as it strives to remain profitable and minimise potential environmental impacts. In particular, disposing of large volumes of shed effluent is an ongoing concern (Bolan et al. 2009; Houlbrooke et al. 2004). Land application of this effluent has become standard practice in New Zealand as the environmental and economic benefits have been clearly identified (Cameron et al. 1997). However, excessive irrigation with nutrient-dense effluent can overload soils with nitrogen $(\mathrm{N})$, phosphorus $(\mathrm{P})$, and potassium (K). These problems can be amplified where the effluent-treated area is small or the farming system has rapidly intensified. Negative effects on animal health (e.g. grass staggers and milk fever) and the environment (e.g. nutrient leaching) can occur as a consequence (Wang et al. 2004; Houlbrooke et al. 2008). These are major concerns for farmers, regional councils and the wider community. In 2007, a 3 year project was initiated to investigate management practices that reduce these risks and enhance nutrient use efficiency. Two central themes were identified, both involving the strategic use of maize to manage dairy shed effluent. These were: 1) growing maize to mine nutrients from nutrient-rich, effluent treated dairy farm soils, and, 2) using effluent as a nutrient source for maize grown on nutrient-depleted cropping soils. This paper addresses the first of these themes.

Maize is ideal for mining nutrients because it commonly produces a biomass above $20 \mathrm{t} \mathrm{DM} / \mathrm{ha}$ (Li et al. 2009). At average $\mathrm{N}, \mathrm{P}$ and $\mathrm{K}$ concentrations in the plant tissue, crop removal can easily exceed $250 \mathrm{~kg} \mathrm{~N}$, $40 \mathrm{~kg} \mathrm{P}$ and $250 \mathrm{~kg} \mathrm{~K} / \mathrm{ha} / \mathrm{season}$. The results of Years 1 and 2 of the project demonstrated there was a clear opportunity for farmers to use maize to reduce nutrient levels in nutrient-rich soils (predominantly those with a history of long-term, permanent pasture that had received regular effluent irrigation). Across nine replicated trials in the Waikato and Manawatu, crops grown without starter or side-dress fertiliser yielded $26.1 \mathrm{t} \mathrm{DM} / \mathrm{ha}$ and removed approximately $300 \mathrm{~kg} \mathrm{~N}, 45 \mathrm{~kg} P$ and $375 \mathrm{~kg}$ $\mathrm{K} /$ ha (Johnstone \& Arnold 2008; Johnstone et al. 2009). This was supplied entirely from the reserves in the soil. Importantly, there was no significant loss of crop yield compared with fully fertilised plots that received starter plus side-dress fertiliser (the industry standard) in the same paddock. Fertiliser cost savings were high in these trials $(\$ 150-\$ 350 / \mathrm{ha})$. The aim of research in the final year of this project was to identify if the nutrient reserves (particularly $\mathrm{N}$ ) in soils with a pasture history and regular effluent irrigation continued to supply sufficient $\mathrm{N}$ for maize in the second consecutive season of cropping.

\section{Method}

\section{Trial background}

Two sites located in Waikato were chosen to quantify $\mathrm{N}$ supply from nutrient-rich dairy soils in the second consecutive season of silage maize. Adjacent areas in both paddocks were used in the previous summer to quantify initial $\mathrm{N}$ supply following cultivation (Johnstone et al. 2009). Each paddock had been in 
Table 1 Summary of key production details at the trial sites, 2009-2010.

\begin{tabular}{lcc}
\hline & Site 1 & Site 2 \\
\hline Soil type & $\begin{array}{c}\text { Kereone } \\
\text { silt loam }\end{array}$ & $\begin{array}{c}\text { Otorohanga } \\
\text { silt loam }\end{array}$ \\
Bulk density $\left(\mathrm{g} / \mathrm{cm}^{3}\right)$ & 0.7 & 0.7 \\
Fertility indicators & & \\
Soil $\mathrm{pH}$ & 6.1 & 5.8 \\
Olsen P (mg/L) & 22 & 25 \\
MAF K test & 15 & 10 \\
AMN $(\mu \mathrm{g} / \mathrm{g})$ & 159 & 109 \\
Total C (\%) & 7.7 & 7.7 \\
Total N (\%) & 0.91 & 0.86 \\
Base fertiliser & Nil & Nil \\
Sowing date & 2 October & 28 October \\
Maize hybrid & $38 \mathrm{H} 20$ & $34 \mathrm{~B} 23$ \\
Plant popln. (000/ha) & 105 & 108 \\
Harvest date & 2 March & 23 March \\
\hline
\end{tabular}

aSoil $\mathrm{pH}$, Olsen $\mathrm{P}$ and MAF K measured before sowing. Anaerobically mineralisable $N(A M N)$, total $C$ and total $N$ were measured at sowing. All measurements were based on soil samples $(0-15 \mathrm{~cm})$ collected from each replicate.

pasture for at least 10 years and had received repeated irrigation with shed effluent during this time (4-5 applications annually following regular grazing by the dairy herd). Annual ryegrass was sown between maize seasons to minimise $\mathrm{N}$ leaching. No $\mathrm{N}$ fertiliser was applied to the ryegrass. Both sites were conventionally cultivated in the spring (September and October) and sown in maize using a commercial precision planter. With the exception of fertiliser management, each crop was grown according to standard farmer practices. Sites were not irrigated. A summary of key production details at each site is provided in Table 1.

\section{Experimental design}

Three approaches to fertiliser management were investigated at both sites. These included a no fertiliser control (NF), starter fertiliser only (SF) and starter and side-dress fertiliser (SSF). The control had received no $\mathrm{N}$ fertiliser since the trials commenced in October 2008. Starter and side-dress fertiliser rates were chosen to represent typical practice in the region $(36 \mathrm{~kg} \mathrm{~N} / \mathrm{ha}$ as starter, $92 \mathrm{~kg} \mathrm{~N} / \mathrm{ha}$ as side-dress). Starter was banded as di-ammonium phosphate at sowing and side-dress $\mathrm{N}$ was broadcast as urea 6-8 weeks after sowing (WAS). No extra P or K fertiliser was applied to NF plots because levels at both sites were above the thresholds accepted as sufficient for maize (Olsen $\mathrm{P}>15, \mathrm{MAF} \mathrm{K}>4$ ); these thresholds are supported by the work of Reid et al. (2002). Experimental design in each paddock was a randomised complete block comparing three treatments (NF, SF and SSF), which were replicated 5 times. Individual plots were 8 rows wide and in most cases at least $50 \mathrm{~m}$ long.

\section{Measurements}

Soil mineral $\mathrm{N}(\mathrm{minN})$ was measured before cultivation (as an indicator of baseline levels) and at harvest. In each instance minN was the sum of ammonium- $\mathrm{N}\left(\mathrm{NH}_{4}-\mathrm{N}\right)$ and nitrate- $\mathrm{N}\left(\mathrm{NO}_{3}-\mathrm{N}\right)$ which were both measured. Before cultivation, a composite sample of five soil cores was collected from each individual replicate at the two sites. At harvest all NF, SF and SSF plots were soil sampled. On this occasion three soil cores were collected mid row and one from within the plant row of each plot to form a composite sample. Sampling depth was 0-30 $\mathrm{cm}$ and $30-60 \mathrm{~cm}$ in all instances. Standard analytical methods were used to measure soil $\mathrm{minN}$ at a commercial laboratory. This included extraction in $2 \mathrm{M} \mathrm{KCl}$ followed by Berthelot colorimetry $\left(\mathrm{NH}_{4}-\mathrm{N}\right)$ or further cadmium reduction and then NED colorimetry $\left(\mathrm{NO}_{3}-\mathrm{N}\right)$.

Silage yields at both sites were measured when maize kernels were visually assessed to be at the twothirds milk line. The harvested sub-plot area was 2.5 $\mathrm{m}$ long by two maize rows wide, a protocol adapted from earlier studies on sampling variability in maize by Shaw \& Hedderley (2007). For consistency, the initial starting point in each sub-plot was selected in between two adjacent plants. A standard cutting height of $10 \mathrm{~cm}$ was used to mimic the commercial harvesting practice. Plant population and total fresh plant biomass were determined in each sub-plot. A sub-sample of 10 random plants were mulched and a $2 \mathrm{~kg}$ sample collected from all plots and analysed for dry matter content (\% DM) and total $\mathrm{N}$ concentration. Total dry matter yield was calculated using sub-plot yield and \% DM.

\section{Statistical analyses}

Relevant data were analysed using ANOVA procedures. Least significant difference (LSD) values were calculated to separate treatment means and were based on $\mathrm{P}<0.05$.

\section{Results}

The response of key crop indicators and soil minN at harvest to fertiliser practice is summarised in Table 2 . Fertiliser practice had no effect on final population, which averaged 104000 (Site 1) and 107000 plants/ ha (Site 2). These populations were comparable to the targeted sowing rate at Site 1 and Site 2 (105000 and $108000 \mathrm{plants} / \mathrm{ha}$, respectively). There was no effect of fertiliser practice on silage yield at Site 1. By contrast, there was a significant response $(\mathrm{P}=0.05)$ to fertiliser at Site 2, where yields were greater under the SF and SSF treatments. This was related to significantly higher $(\mathrm{P}=$ $0.05)$ individual plant biomass under these treatments ( $\sim 10 \%$ higher, data not shown). DM content was unaffected by fertiliser and fell largely within the target range for ensiling (32-38\% DM). Fertiliser practice 
Table 2 Effect of fertiliser practice on crop indicators and soil minN at harvest, 2009-2010.

\begin{tabular}{|c|c|c|c|c|c|c|}
\hline Fertiliser practice & $\begin{array}{l}\text { Plant popln. } \\
\text { (000/ha) }\end{array}$ & $\begin{array}{l}\text { Silage yield } \\
\text { (t DM/ha) }\end{array}$ & $\begin{array}{c}\text { Dry matter } \\
\text { content (\% DM) }\end{array}$ & $\begin{array}{c}\text { Total N conc. } \\
(\% \mathrm{~N})\end{array}$ & $\begin{array}{l}\text { Crop N uptake } \\
\text { (kg N/ha) }\end{array}$ & $\begin{array}{c}\text { Soil } \operatorname{minN}(\mathrm{kg} \\
\mathrm{N} / \mathrm{ha}, 0-60 \mathrm{~cm})\end{array}$ \\
\hline \multicolumn{7}{|l|}{ Site 1} \\
\hline $\mathrm{NF}$ & 104 & 27.9 & 37 & 1.24 & 347 & 65 \\
\hline SF & 101 & 26.2 & 37 & 1.23 & 321 & 84 \\
\hline SSF & 107 & 28.1 & 38 & 1.24 & 351 & 145 \\
\hline$P$ value ${ }^{a}$ & NS (18) & NS (4.8) & NS (2) & NS (0.13) & NS (69) & $<0.01(32)$ \\
\hline \multicolumn{7}{|l|}{ Site 2} \\
\hline NF & 107 & 27.9 & 31 & 1.06 & 296 & 35 \\
\hline SF & 106 & 31.0 & 33 & 1.19 & 370 & 68 \\
\hline SSF & 107 & 31.1 & 33 & 1.17 & 364 & 165 \\
\hline$P$ value & NS (8) & $0.05(2.9)$ & NS (3) & NS (0.25) & NS (85) & $<0.01(51)$ \\
\hline
\end{tabular}

${ }^{a} \mathrm{NS}=$ not statistically significant at $\mathrm{P}<0.05$. LSD values are provided in parentheses and represent the smallest difference necessary between two means for a statistically significant test result $(\mathrm{P}<0.05)$.

Table 3 Estimated supply of N from soil in NF plots during the second season, 2009-2010.

\begin{tabular}{|c|c|c|c|c|}
\hline & \multirow{2}{*}{$\begin{array}{c}\text { Before cultivation } \\
\text { Soil minN } \\
(\mathrm{kg} \mathrm{N} / \mathrm{ha})^{\mathrm{a}}\end{array}$} & \multicolumn{2}{|c|}{ At harvest } & \multirow{2}{*}{$\begin{array}{l}\mathrm{N} \text { supplied during the } \\
\text { growing season }(\mathrm{kg} \\
\mathrm{N} / \mathrm{ha})^{\mathrm{c}}\end{array}$} \\
\hline & & $\begin{array}{l}\text { Soil minN } \\
(\mathrm{kg} \mathrm{N} / \mathrm{ha})^{\mathrm{a}}\end{array}$ & $\begin{array}{l}\text { Crop uptake } \\
(\mathrm{kg} \mathrm{N} / \mathrm{ha})^{\mathrm{b}}\end{array}$ & \\
\hline Site 1 & 60 & 65 & 347 & 352 \\
\hline Site 2 & 43 & 35 & 296 & 288 \\
\hline
\end{tabular}

aSoil $\operatorname{minN}$ was measured to $60 \mathrm{~cm}$. ${ }^{\mathrm{b}} \mathrm{Crop}$ uptake reflects the $\mathrm{N}$ in the above ground biomass. ${ }^{\mathrm{N}} \mathrm{N}$ supplied during the growing season was calculated using the sum of soil $\operatorname{minN}$ and crop uptake at harvest minus soil minN before cultivation.

had no effect on total $\mathrm{N}$ concentration in maize at either site. There was no significant effect of fertiliser practice on crop $\mathrm{N}$ uptake at either site. At both sites, SSF significantly increased residual soil $\operatorname{minN}$ in the top 60 $\mathrm{cm}$ at harvest compared to NF and SF approaches. This reflected the balance of extra $\mathrm{N}$ that was side-dressed but not ultimately required by the crop. Most $\operatorname{minN}$ in the top $60 \mathrm{~cm}$ was found between $0-30 \mathrm{~cm}(64-78 \%$ across sites, data not shown). This was unaffected by fertiliser practice. $\mathrm{NO}_{3}-\mathrm{N}$ was the predominant $\mathrm{N}$ form in the top $60 \mathrm{~cm}$ at harvest $(89 \%$ at Site $1,87 \%$ at Site 2 , data not shown).

A simple $\mathrm{N}$ balance was used to estimate the $\mathrm{N}$ supplied by the soil (i.e. sum of soil $\mathrm{minN}$ and crop $\mathrm{N}$ at harvest minus baseline soil minN levels before cultivation) during the growing season (Table 3 ). This balance did not account for $\mathrm{N}$ losses from the system. At both sites minN in NF plots at harvest was similar to that before cultivation. This was despite crop uptake of $347 \mathrm{~kg} \mathrm{~N}$ (Site 1) and $296 \mathrm{~kg} \mathrm{~N} / \mathrm{ha}$ (Site 2). This was supplied from new mineralisation in the top 60 $\mathrm{cm}$ or from residual $\mathrm{N}$ sitting below $60 \mathrm{~cm}$. Combined crop uptake over the consecutive seasons (2008-2009, 2009-2010) was 657 and $580 \mathrm{~kg} \mathrm{~N} / \mathrm{ha}$ at Site 1 and Site 2, respectively. This included 310 and $284 \mathrm{~kg} \mathrm{~N} /$ ha from the previous maize crop at each site (Johnstone et al. 2009) for plots that had received no $\mathrm{N}$ fertiliser in either season.
To test the standard approach a farmer may take when deciding whether to fertilise a crop AmaizeN Lite was used. A full summary of this industry decision support tool is provided by Li et al. (2006) and Pearson et al. (2009). The tool was initiated using soil minN measured at sowing, maize hybrid selection, planting density, sowing date, and average 30 -year weather data. This reflected the information available to farmers at the start of a season. Using this approach, AmaizeN Lite predicted that neither crop would require $\mathrm{N}$ fertiliser during the season. This prediction was correct at Site 1, but incorrect at Site 2 where a small yield penalty was associated with the NF treatment.

\section{Discussion}

Our results showed that pasture soils with a history of regular effluent irrigation are able to supply large quantities of $\mathrm{N}$ to silage maize in the second season (up to $350 \mathrm{~kg} \mathrm{~N} / \mathrm{ha}$ ). At Site 1 this supply was sufficient to meet $\mathrm{N}$ demand of the crop with no extra fertiliser, while at Site 2 it was not. At Site 2 a nominal amount of starter fertiliser (36 kg N/ha) maximised yield. There was no clear evidence that the different yield potentials between sites (related to site conditions and hybrid selections) influenced these dynamics. Matching optimal $\mathrm{N}$ supply (no fertiliser at Site 1 and starter fertiliser only at Site 2) against crop demand minimised residual minN left in the soil at harvest, reducing the 
risk of winter leaching. At both sites, side-dressed $\mathrm{N}$ was particularly inefficient, with most of it remaining in the soil at harvest. Fertiliser cost savings ranged from $\$ 310 /$ ha (Site 1) to $\$ 125 /$ ha (Site 2), excluding the cost of application.

To ensure profitable and sustainable nutrient use farmers need to know when extra fertiliser should be applied. The AmaizeN tool was accurate at predicting that the nutrient-rich soils would supply sufficient $\mathrm{N}$ to meet maize crop demand at Site 1 but slightly underestimated $\mathrm{N}$ demand at Site 2. It is useful to note that the amount of extra $\mathrm{N}$ fertiliser required to maximise yield at Site 2 was minimal ( $\sim 36 \mathrm{~kg} \mathrm{~N} / \mathrm{ha})$, suggesting AmaizeN predictions were not markedly off target. Running the tool retrospectively at this site at the end of the season confirmed this assertion; based on soil minN at sowing and actual weather during the season, AmaizeN predicted that an extra $29 \mathrm{~kg} \mathrm{~N} / \mathrm{ha}$ was required to achieve maximum yield. Sampling to depth (below $60 \mathrm{~cm}$ ) and sampling as close to making fertiliser decisions as possible will give the most accurate recommendation when using this tool. Because soil minN is variable both spatially and seasonally a more robust indicator of the soils $\mathrm{N}$ mineralisation potential would improve predictions made by AmaizeN.

\section{Conclusions}

High yielding maize crops can help reduce $\mathrm{N}$ levels in nutrient-rich dairy soils. There is a strong case to apply no $\mathrm{N}$ fertiliser to silage maize in the first season following pasture that received regular effluent irrigation, while in the second consecutive season reduced $\mathrm{N}$ fertiliser inputs are possible. Side-dress fertiliser was particularly ineffective in both trials and led to high residual soil minN levels at harvest. This approach to managing nutrients can create win-win outcomes for farmers and the community; fertiliser costs will be minimised, as will the potential for nutrient loss to waterways. Further work is required to give farmers certainty as to when extra fertiliser is required, particularly in the second season following permanent pasture. This would include a greater number of trials that span more soil types, background fertility levels, geographic regions and seasonal conditions.

\section{ACKNOWLEDGEMENTS}

This work was funded by the MAF Sustainable Farming Fund (07-037), Foundation for Arable Research, DairyNZ, Environment Waikato and Genetic Technologies Ltd.

\section{REFERENCES}

Bolan, N.S.; Laurenson, S.; Luo, J.; Sukias, J. 2009. Integrated treatment of farm effluents in New
Zealand's dairy operations. Bioresource Technology 100: 5490-5497.

Cameron, K.C.; Di, H.J.; McLaren, R.G. 1997. Is soil an appropriate dumping ground for our wastes? Australian Journal of Soil Research 35: 995-1035.

Houlbrooke, D.J.; Horne, D.J.; Hedley, M.J.; Hanly, J.A.; Snow, V.O. 2004. A review of literature on the land treatment of farm-dairy effluent in New Zealand and its impact on water quality. New Zealand Journal of Agricultural Research 47: 499-511.

Houlbrooke, D.J.; Horne, D.J.; Hedley, M.J.; Snow, V.O.; Hanly, J.A. 2008. Land application of farm dairy effluent to a mole and pipe drained soil: implications for nutrient enrichment of winter-spring drainage. Australian Journal of Soil Research 46: 45-52.

Johnstone, P.; Arnold, N. 2008. Managing dairy shed effluent using maize. Crop \& Food Research Confidential Report No. 2107. NZ Institute of Crop $\&$ Food Research Ltd, Lincoln, New Zealand.

Johnstone, P.; Parker, M.; Kaufler, G.; Arnold, N.; Pearson, A. 2009. Using maize to maize to manage dairy shed effluent - maximising the margin and minimising the footprint. pp. 557. In: Farming's Future. Eds. Currie, L.D.; Christensen, C.L. Occasional Report No. 23. Fertiliser and Lime Research Centre, Massey University, Palmerston North, New Zealand.

Li, FY.; Jamieson, P.D.; Pearson, A.J. 2006. AmaizeN: developing a decision support tool to optimise nitrogen management of maize. Agronomy New Zealand 36: 61-70.

Li, F.L.; Johnstone, P.R.; Pearson, A.; Fletcher, A.; Jamieson, P.D.; Brown, H.E.; Zyskowski, R.F. 2009. AmaizeN: A decision support system for optimizing nitrogen management of maize. NJAS -Wageningen Journal of Life Sciences 57: 93-100.

Pearson, A.; Li, F.; Johnstone, P.; Jamieson, P. 2009. AmaizeN - a yield and $\mathrm{N}$ fertiliser forecasting tool for maize silage and grain crops. pp. 95-100. In: Nutrient management in a rapidly changing world. Eds. Currie, L.D.; Lindsay, C.L. Occasional Report No. 22. Fertilizer and Lime Research Centre, Massey University, Palmerston North, New Zealand.

Reid, J.B.; Stone, P. J.; Pearson, A.J.; Wilson, D.R. 2002. Yield response to nutrient supply across a wide range of conditions: 2. Analysis of maize yields. Field Crops Research 77: 173-189.

Shaw, S.; Hedderley, D. 2007. Sampling protocols for large plot trials. Crop \& Food Research Confidential Report No. 1977. NZ Institute of Crop \& Food Research Ltd, Lincoln, New Zealand.

Wang, H.; Magesan, G.; Bolan, N. 2004. An overview of the environmental effects of land application of farm effluents. New Zealand Journal of Agricultural Research 47: 389-403. 